HEALTH POLICY

\title{
IIIIII Impact of Out-of-Pocket Spending Caps on Financial Burden of those with Group Health Insurance
}

\author{
Kevin R. Riggs, MD, MPH ${ }^{1,2,3}$, Christine Buttorff, $\mathrm{PhD}^{4}$, and G. Caleb Alexander, $M D, M^{1,3,5}$ \\ 'Division of General Internal Medicine, Johns Hopkins University School of Medicine, Baltimore, MD, USA; ${ }^{2}$ Johns Hopkins Berman Institute of \\ Bioethics, Baltimore, MD, USA; ${ }^{3}$ Center for Drug Safety and Effectiveness, Johns Hopkins University, Baltimore, MD, USA; ${ }^{4}$ RAND Corporation, \\ Arlington, VA, USA; ${ }^{5}$ Department of Epidemiology, Johns Hopkins Bloomberg School of Public Health, Baltimore, MD, USA.
}

BACKGROUND: The Affordable Care Act (ACA) mandates that all private health insurance include outof-pocket spending caps. Insurance purchased through the ACA's Health Insurance Marketplace may qualify for income-based caps, whereas group insurance will not have income-based caps. Little is known about how out-of-pocket caps impact individuals' health care financial burden.

OBJECTIVE: We aimed to estimate what proportion of non-elderly individuals with group insurance will benefit from out-of-pocket caps, and the effect that various cap levels would have on their financial burden.

DESIGN: We applied the expected uniform spending caps, hypothetical reduced uniform spending caps (reduced by one-third), and hypothetical income-based spending caps (similar to the caps on Health Insurance Marketplace plans) to nationally representative data from the Medical Expenditure Panel Survey (MEPS).

PARTICIPANTS: Participants were non-elderly individuals (aged < 65 years) with private group health insurance in the 2011 and 2012 MEPS surveys ( $n=26,666$ ).

MAIN MEASURES: (1) The percentage of individuals with reduced family out-of-pocket spending as a result of the various caps; and (2) the percentage of individuals experiencing health care services financial burden (family outof-pocket spending on health care, not including premiums, greater than $10 \%$ of total family income) under each scenario.

KEY RESULTS: With the uniform caps, $1.2 \%$ of individuals had lower out-of-pocket spending, compared with $3.8 \%$ with reduced uniform caps and $2.1 \%$ with income-based caps. Uniform caps led to a small reduction in percentage of individuals experiencing financial burden (from $3.3 \%$ to $3.1 \%$ ), with a modestly larger reduction as a result of reduced uniform caps $(2.9 \%)$ and incomebased caps (2.8\%).

CONCLUSIONS: Mandated uniform out-of-pocket caps for those with group insurance will benefit very few individuals, and will not result in substantial reductions in financial burden.

KEY WORDS: health insurance; health reform; health care costs.

Received July 9, 2014

Revised October 16, 2014

Accepted November 17, 2014

Published online December 4, 2014
J Gen Intern Med 30(5):683-8

DOI: $10.1007 / \mathrm{s} 11606-014-3127-z$

(C) Society of General Internal Medicine 2014

\section{INTRODUCTION}

The Affordable Care Act (ACA) includes numerous provisions aimed at improving the financial protection offered by health insurance and reducing financial burden caused by high health care costs. In addition to prohibiting life-time benefit caps, prohibiting exclusion of pre-existing conditions, and mandating coverage for certain services such as preventive screenings, the ACA also seeks to directly reduce financial burden by capping individuals' and families' annual out-of-pocket payments, which include deductibles, co-insurance and copayments. One reason these caps are of interest is that being "underinsured"-having insurance and yet being exposed to a high level of financial risk $^{1}$ - and the associated financial burden contribute to numerous adverse consequences, such as non-compliance, ${ }^{2}$ delayed or forgone care, ${ }^{3}$ and bankruptcy. ${ }^{4}$

The recent health care reform was largely motivated by the "crisis" of high uninsurance," and much of the attention generated by the ACA has focused on the new Health Insurance Marketplace ("exchanges") and the eight million Americans who signed up during the initial open enrollment. ${ }^{6}$ However, reform was also motivated to improve insurance and lower costs for all Americans, and since the majority of non-elderly Americans will remain covered by insurance obtained through their employers, provisions in the ACA that affect group (i.e., employer-sponsored) insurance have the potential to impact the financial burden of many more individuals than the exchanges. Out-of-pocket spending caps are one important measure that improves the financial protection of health insurance, although the caps offer different protection to those on the exchanges and those with group insurance. Those who purchase insurance through the exchanges are eligible for income-based out-of-pocket caps ("income-based caps"), while those with group insurance are not ("uniform caps") - the ACA mandates that non-grandfathered group 
insurance plans (plans are considered grandfathered if they have not made significant changes to benefit structure after 2010) have out-of-pocket caps, but those caps can be as high as those set for Health Savings Account-qualified plans (highdeductible health plans). ${ }^{7}$

The effect of out-of-pocket caps on reducing financial burden is largely unknown, even though the majority of employer-sponsored plans had an individual out-of-pocket cap prior to implementation of the ACA. ${ }^{8}$ Prior studies on elements of insurance associated with high financial burden have largely focused on the role of high deductibles (i.e., upfront cost sharing), which are associated with financial burden, especially for those with chronic medical conditions or low incomes. ${ }^{9}$ We estimate the percentage of individuals that will have reduced family out-of-pocket costs, and the effect on measures of financial burden that various out-of-pocket cap scenarios would have among the non-elderly with group insurance.

\section{METHODS}

\section{Data}

We used data from the 2011 and 2012 Medical Expenditure Panel Survey (MEPS). MEPS is a publicly available survey on health care expenditures and utilization conducted by the Agency for Healthcare Research and Quality. The survey includes a stratified and clustered random sample of National Health Interview Survey households, and employs statistical weights that can be used to produce nationally representative estimates for the civilian, non-institutionalized US population. MEPS provides information on health care access and use, socioeconomic characteristics, employment, access to care, and related topics. MEPS is described in detail elsewhere. ${ }^{10,11}$ Because MEPS data is de-identified and publically available, this study did not require review by an institutional review board.

We included individuals under age 65 who had private health insurance for each month of the year. Given that the non-group insurance market is likely to undergo significant disruption as a result of the ACA, ${ }^{12}$ we excluded those with non-group insurance $(4.2 \%$ of the weighted population of non-elderly with continuous private insurance). With these inclusion criteria, the survey included 26,666 person-years, representing a weighted annualized population of approximately 147 million people. For family-level estimates, we included families with at least one qualifying individual.

\section{Variables and Analysis}

Determination of Health Care Spending. Out-of-pocket caps mandated by the ACA only apply to spending on certain services-those considered essential health benefits. For insurance offered on the exchanges, the ten categories of essential health benefits are defined explicitly: ambulatory patient services; emergency services; hospitalization; maternity and newborn care; mental health and substance use disorder services, including behavioral health treatment; prescription drugs; rehabilitative and habilitative services and devices; laboratory services; preventive and wellness services and chronic disease management; and pediatric services, including oral and vision care. The ACA does not similarly define essential health benefits for large group and self-insured plans, but plan benefits for those plans are still subject to review by the Secretary of Health and Human Services, and the out-ofpocket caps for non-grandfathered plans will apply to essentially the same services as exchange plans. ${ }^{7}$

Since not all out-of-pocket spending will be subject to the caps, we only applied out-of-pocket spending on eligible services (i.e., on essential health benefits) towards the caps. To approximate eligible services, we subtracted out-of-pocket spending for chiropractic services for all patients, and optometry, vision and contacts, and dental care for individuals 18 years and older from total out-of-pocket spending. However, we included all health care spending in measures of burden.

Measures of Financial Burden. We defined health care services burden as family out-of-pocket spending on health care services greater than $10 \%$ of total family income, not including premiums. This measure is designed to identify those who are underinsured. ${ }^{13}$ Total burden includes out-of-pocket spending on health care services and premiums. Several other thresholds are commonly used to define financial burden. As one alternative, we used a threshold of $20 \%$ of total family income. As another alternative, we used a threshold of $5 \%$ for those under $200 \%$ of the federal poverty level (FPL), and $10 \%$ for those above. Other definitions of financial burden have been used in the literature, but these definitions are particularly common. ${ }^{13-17}$

We defined financial burden at a family level, since families typically share resources and would likely be affected by another family member's high out-of-pocket health care spending. Individuals who were considered part of the family as defined by MEPS, but who were outside of our sample would still contribute to family income. However, spending of those outside of our sample was not counted in our measure of family out-of-pocket spending for our primary analyses. In sensitivity analyses, we included only families in which all members had group insurance $(74.9 \%$ of the final sample). The results of these analyses yielded virtually identical findings and are not reported herein. We adjusted all dollar measures to 2014 US dollars using the urban Consumer Price Index. ${ }^{18}$ 
Table 1. Out-of-Pocket Spending Cap Scenarios

\begin{tabular}{|c|c|c|c|}
\hline & \multicolumn{3}{|c|}{ Family Income as \% of Federal Poverty Level } \\
\hline & $<\mathbf{2 0 0}$ & $200-250$ & $400+$ \\
\hline \multicolumn{4}{|l|}{ Uniform caps } \\
\hline Amount & $\$ 6,350 /$ & $\$ 6,350 /$ & $\$ 6,350 /$ \\
\hline $\begin{array}{l}\text { (individual/ } \\
\text { family) }\end{array}$ & $\$ 12,700$ & $\$ 12,700$ & $\$ 12,700$ \\
\hline \multicolumn{4}{|c|}{ Reduced uniform caps } \\
\hline Reduction* & one-third & one-third & one-third \\
\hline Amount & $\$ 4,233 /$ & $\$ 4,233 /$ & $\$ 4,233 /$ \\
\hline $\begin{array}{l}\text { (individual/ } \\
\text { family) }\end{array}$ & $\$ 8,267$ & $\$ 8,267$ & $\$ 8,267$ \\
\hline \multicolumn{4}{|c|}{ Income-based caps } \\
\hline Reduction* & two-thirds & one-fifth & none \\
\hline Amount & $\$ 2,117 /$ & $\$ 5,080 /$ & $\$ 6,350 /$ \\
\hline $\begin{array}{l}\text { (individual / } \\
\text { family) }\end{array}$ & $\$ 4,233$ & $\$ 10,160$ & $\$ 12,7000$ \\
\hline
\end{tabular}

* Reduction relative to the uniform caps

Cap Scenarios. Out-of-pocket cap scenarios are summarized in Table 1 . The uniform caps are modeled after those mandated by the ACA for non-grandfathered private group insurance plans. These caps can be as high as those required for Health Savings Account-qualified plans, which was $\$ 6,350$ for individuals and $\$ 12,700$ for families in 2014. The reduced uniform caps are an arbitrary one-third reduction, compared to the uniform caps.

The income-based cap scenario is modeled after the caps available through the exchanges. Individuals with family incomes between 100 and $200 \%$ of FPL have caps reduced by two thirds (compared to those for Health Savings Accountqualified plans); those between 200 and $250 \%$ of FPL have caps reduced by one fifth; those greater than $250 \%$ of FPL are subject to the full caps. The ACA initially called for more generous reductions in out-of-pocket caps, but they were adjusted to conform with pre-specified actuarial values of available plans. ${ }^{19}$
Individuals with family income $<100 \%$ of FPL are not eligible for reduced caps on the exchanges, as the intent of the law was for these individuals to be covered by expanded Medicaid. However, we applied the same income-based caps for those with incomes 100-200\% of FPL to those with income $<100 \%$ of FPL for the purposes of this study.

Outcome Measures. Our main outcome of interest was the percentage of individuals with reduced out-of-pocket spending as a result of the various cap scenarios. Additionally, we calculated the percentage of individuals with high financial burden, calculated without a mandated cap and under the various cap scenarios.

Finally, we calculated the "cost" of the caps (i.e., the amount of cost-shifting from out-of-pocket to insurancecovered). Assuming that the caps would not induce addition spending (i.e., no moral hazard), spending that would have been out-of-pocket without the caps is "shifted" to the insurance company, which may result in higher premiums. Out-ofpocket spending above the respective caps was summed across the population and divided by the number of people in the population to calculate the per-person cost-shifting (to approximate per-person premium increase that would cover the shifted costs).

Analysis. We applied each cap scenario to the data set, which reflected individuals' actual health care expenditures from 2011 or 2012. We used descriptive statistics to quantify spending and financial burden under the different scenarios. We used Stata version 13.1 for all statistical analyses, and applied the weights provided in MEPS to account for the complex sampling design.

Table 2. Health Care Spending of Non-Elderly Individuals with Group Health Insurance

\begin{tabular}{|c|c|c|c|c|}
\hline & \multicolumn{4}{|c|}{ Family Income as \% of Federal Poverty Level } \\
\hline & $<\mathbf{2 0 0}$ & 200-250 & $250+$ & Total \\
\hline \multicolumn{5}{|l|}{ Individual level measures } \\
\hline Individuals (unweighted) & 4,854 & 2,421 & 19,391 & 26,666 \\
\hline Population (annualized, weighted) & $19,377,021$ & $11,114,391$ & $114,883,886$ & $145,375,298$ \\
\hline$\%$ of total included sample & $13.33 \%$ & $7.65 \%$ & $79.03 \%$ & $100.00 \%$ \\
\hline$\%$ of income-level who are included & $18.08 \%$ & $38.56 \%$ & $65.15 \%$ & $46.55 \%$ \\
\hline Individual medical costs, mean (SE) & $\$ 3,740(224)$ & $\$ 3,741(285)$ & $\$ 4,273(169)$ & $\$ 4,161(139)$ \\
\hline Individual OOP medical costs, mean (SE) & $\$ 515(30)$ & $\$ 521(36)$ & $\$ 686(18)$ & $\$ 650(16)$ \\
\hline $\begin{array}{l}\text { Individual OOP medical costs on EHB, } \\
\text { mean (SE) }\end{array}$ & $\$ 404(26)$ & $\$ 418(31)$ & $\$ 525(16)$ & $\$ 501(15)$ \\
\hline \multicolumn{5}{|l|}{ Family level measures } \\
\hline Family Income, median (SE) [mean] & $\begin{array}{l}\$ 22,206(516) \\
{[24,049]}\end{array}$ & $\begin{array}{l}\$ 38,447(646) \\
{[42,905]}\end{array}$ & $\begin{array}{l}\$ 86,203(1,237) \\
{[103,148]}\end{array}$ & $\begin{array}{l}\$ 71,275(1,145) \\
{[86,236]}\end{array}$ \\
\hline Family medical costs, mean (SE) & $\$ 6,173(405)$ & $\$ 7,377(615)$ & $\$ 8,681(358)$ & $\$ 8,192(295)$ \\
\hline Family OOP medical costs, mean (SE) & $\$ 854(51)$ & $\$ 1,023(75)$ & $\$ 1,415(40)$ & $\$ 1,298(35)$ \\
\hline $\begin{array}{l}\text { Family OOP medical costs on EHB, mean } \\
\text { (SE) }\end{array}$ & $\$ 676(45)$ & $\$ 819(64)$ & $\$ 1,080(37)$ & $\$ 998(32)$ \\
\hline Family OOP premiums, mean (SE) & $\$ 1,866(82)$ & $\$ 2,535(127)$ & $\$ 3,057(61)$ & $\$ 2,832(51)$ \\
\hline
\end{tabular}

OOP Out-of-Pocket; EHB Essential Health Benefits; SE Standard Error

Dollars are inflated to 2014 values, rounded to the nearest dollar 


\section{RESULTS}

\section{Spending by Non-Elderly Individuals with Group Health Insurance}

Individual and family-level health care spending is shown in Table 2. Although this population represents approximately half of the US population, included individuals were relatively wealthy, with a median family income of $\$ 71,275$.

\section{Caps Resulting in Lower Out-of-Pocket Spending}

The percentage of individuals expected to benefit from the out-of-pocket caps by having lower out-of-pocket spending, as well as their mean savings, is shown in Table 3. With the uniform caps, $1.2 \%$ of individuals would save $\$ 4,147$ on average. Almost twice as many would benefit with income-based caps, and more than three times as many individuals would benefit with reduced uniform caps, compared to uniform caps. With income-based caps, among those eligible for reduced caps (i.e., individuals with family incomes less than $250 \%$ of FPL), close to four times as many benefit, compared to uniform caps.

\section{High Financial Burden}

The percentage of individuals with high health care services burden and total burden is shown in Table 4 . The uniform caps decreased the percentage of individuals with high health care services burden from $3.3 \%$ to $3.1 \%$. Implementing reduced uniform caps would reduce the level to $2.9 \%$, while incomebased caps would reduce the level to $2.8 \%$. Reductions in total burden followed a similar pattern.

Table 3. Individuals with Reduced Family Out-of-Pocket Spending as a Result of Caps

\begin{tabular}{|c|c|c|c|c|}
\hline & \multicolumn{4}{|c|}{ Family Income as \% of Federal Poverty Level } \\
\hline & $<200$ & $200-250$ & $250+$ & Total \\
\hline \multicolumn{5}{|l|}{ Uniform caps } \\
\hline $\begin{array}{l}\text { Percent } \\
\text { benefitting } \\
\text { (SE) }\end{array}$ & $\begin{array}{l}2.3 \% \\
(0.9)\end{array}$ & $\begin{array}{l}0.3 \% \\
(0.2)\end{array}$ & $\begin{array}{l}1.1 \% \\
(0.2)\end{array}$ & $\begin{array}{l}1.2 \% \\
(0.2)\end{array}$ \\
\hline $\begin{array}{l}\text { Mean savings } \\
\text { (SE) }\end{array}$ & $\begin{array}{l}\$ 6,025 \\
(2,621)\end{array}$ & $\begin{array}{l}\$ 4,087 \\
(874)\end{array}$ & $\begin{array}{l}\$ 3,470 \\
(791)\end{array}$ & $\begin{array}{l}\$ 4,147 \\
(903)\end{array}$ \\
\hline \multicolumn{5}{|c|}{ Reduced uniform caps } \\
\hline $\begin{array}{l}\text { Percent } \\
\text { benefitting } \\
\text { (SE) }\end{array}$ & $\begin{array}{l}3.2 \% \\
(0.9)\end{array}$ & $\begin{array}{l}2.4 \% \\
(0.8)\end{array}$ & $\begin{array}{l}4.0 \% \\
(0.4)\end{array}$ & $\begin{array}{l}3.8 \% \\
(0.4)\end{array}$ \\
\hline $\begin{array}{l}\text { Mean savings } \\
\text { (SE) }\end{array}$ & $\begin{array}{l}\$ 6,051 \\
(1,976)\end{array}$ & $\begin{array}{l}\$ 1,451 \\
(586)\end{array}$ & $\begin{array}{l}\$ 2,177 \\
(305)\end{array}$ & $\begin{array}{l}\$ 2,590 \\
(380)\end{array}$ \\
\hline \multicolumn{5}{|l|}{ Income-based caps } \\
\hline $\begin{array}{l}\text { Percent } \\
\text { benefitting } \\
\text { (SE) }\end{array}$ & $\begin{array}{l}8.5 \% \\
(1.4)\end{array}$ & $\begin{array}{l}1.1 \% \\
(0.6)\end{array}$ & $\begin{array}{l}1.1 \% \\
(0.3)\end{array}$ & $\begin{array}{l}2.1 \% \\
(0.4)\end{array}$ \\
\hline $\begin{array}{l}\text { Mean savings } \\
\text { (SE) }\end{array}$ & $\begin{array}{l}\$ 3,691 \\
(973)\end{array}$ & $\begin{array}{l}\$ 1,855 \\
(1,164)\end{array}$ & $\begin{array}{l}\$ 3,470 \\
(791)\end{array}$ & $\begin{array}{l}\$ 3,525 \\
(673)\end{array}$ \\
\hline
\end{tabular}

SE Standard Error

Cap scenarios are as shown in Table 1
Table 4. Individuals with High Financial Burden

\begin{tabular}{|c|c|c|c|c|}
\hline & \multicolumn{4}{|c|}{$\begin{array}{l}\text { Family Income as \% of Federal Poverty } \\
\text { Level }\end{array}$} \\
\hline & $<\mathbf{2 0 0}$ & $200-250$ & $250+$ & Total \\
\hline \multicolumn{5}{|l|}{ No mandated caps } \\
\hline $\begin{array}{l}\text { Health care services } \\
\text { burden (SE) }\end{array}$ & $\begin{array}{l}16.4 \% \\
(1.7)\end{array}$ & $\begin{array}{l}3.7 \% \\
(1.0)\end{array}$ & $\begin{array}{l}1.0 \% \\
(0.2)\end{array}$ & $\begin{array}{l}3.3 \% \\
(0.4)\end{array}$ \\
\hline Total burden (SE) & $\begin{array}{l}50.7 \% \\
(2.1)\end{array}$ & $\begin{array}{l}32.5 \% \\
(3.2)\end{array}$ & $\begin{array}{l}11.8 \% \\
(0.7)\end{array}$ & $\begin{array}{l}18.8 \% \\
(0.8)\end{array}$ \\
\hline \multicolumn{5}{|l|}{ Uniform caps } \\
\hline $\begin{array}{l}\text { Health care services } \\
\text { burden (SE) }\end{array}$ & $\begin{array}{l}16.4 \% \\
(1.7)\end{array}$ & $\begin{array}{l}3.7 \% \\
(1.0)\end{array}$ & $\begin{array}{l}0.8 \% \\
(0.1)\end{array}$ & $\begin{array}{l}3.1 \% \\
(0.3)\end{array}$ \\
\hline Total burden (SE) & $\begin{array}{l}50.7 \% \\
(2.1)\end{array}$ & $\begin{array}{l}32.5 \% \\
(3.2)\end{array}$ & $\begin{array}{l}11.5 \% \\
(0.7)\end{array}$ & $\begin{array}{l}18.6 \% \\
(0.8)\end{array}$ \\
\hline \multicolumn{5}{|c|}{ Reduced uniform caps } \\
\hline $\begin{array}{l}\text { Health care services } \\
\text { burden (SE) }\end{array}$ & $\begin{array}{l}16.1 \% \\
(1.7)\end{array}$ & $\begin{array}{l}3.7 \% \\
(1.0)\end{array}$ & $\begin{array}{l}0.5 \% \\
(0.1)\end{array}$ & $\begin{array}{l}2.9 \% \\
(0.3)\end{array}$ \\
\hline Total burden (SE) & $\begin{array}{l}50.5 \% \\
(2.1)\end{array}$ & $\begin{array}{l}32.5 \% \\
(3.2)\end{array}$ & $\begin{array}{l}11.3 \% \\
(0.7)\end{array}$ & $\begin{array}{l}18.3 \% \\
(0.7)\end{array}$ \\
\hline \multicolumn{5}{|l|}{ Income-based caps } \\
\hline $\begin{array}{l}\text { Health care services } \\
\text { burden (SE) }\end{array}$ & $\begin{array}{l}14.0 \% \\
(1.6)\end{array}$ & $\begin{array}{l}3.7 \% \\
(1.0)\end{array}$ & $\begin{array}{l}0.8 \% \\
(0.1)\end{array}$ & $\begin{array}{l}2.8 \% \\
(0.3)\end{array}$ \\
\hline Total burden (SE) & $\begin{array}{l}49.5 \% \\
(2.1)\end{array}$ & $\begin{array}{l}32.5 \% \\
(3.2)\end{array}$ & $\begin{array}{l}11.5 \% \\
(0.7)\end{array}$ & $\begin{array}{l}18.4 \% \\
(0.8)\end{array}$ \\
\hline
\end{tabular}

SE Standard Error

Cap scenarios are as shown in Table 1

High financial burden is defined as family out-of-pocket spending greater than $10 \%$ of family income

Health care services burden includes out-of-pocket expenditures on health care services

Total burden includes out-of-pocket premiums for private insurance and expenditures on health care services

The results using the alternative thresholds for financial burden display similar trends, and are shown in Tables 5 and 6.

Finally, implementing the uniform caps would result in cost-shifting from out-of-pocket to insurance company of $\$ 50$ per person per year, reduced uniform caps $\$ 98$ per person per year, and income-based caps $\$ 76$ per person per year (all compared with no mandated caps).

\section{DISCUSSION}

Our study suggests that implementation of uniform outof-pocket spending caps as mandated by the ACA will benefit very few individuals, and will not lead to substantial reductions in financial burden among those with group health insurance. Implementing reduced uniform caps or income-based caps, similar to those available on the exchanges, would lead to modestly higher reductions. While there are a variety of measures in the ACA that may impact patients' financial burden, our findings demonstrate the limited impact that the currently constructed out-of-pocket spending caps will have.

One reason for the modest reductions that we estimate is that out-of-pocket caps were already common in private insurance prior to the ACA-88\% of those covered in employer-sponsored plans have an individual cap, and more 
than half of these caps are less than $\$ 3,000 .^{8}$ Another reason is that defining financial burden as we have predictably limits impact of the out-of-pocket caps. For example, some with very low income who experience financial burden without a cap would still, by definition, experience financial burden at capped spending (even though the out-of-pocket spending would be reduced). However, this definition of financial burden highlights the debate about what level of cost sharing should be considered affordable. ${ }^{20}$ Since the majority of American families earning less than $400 \%$ of FPL have less than $\$ 3,000$ in accessible savings, ${ }^{21}$ even "capped" out-ofpocket expenses of $\$ 12,700$ are likely to cause hardship for those with low incomes.

Given that so few individuals will likely benefit from the out-of-pocket caps at the current levels, policy makers may choose to adjust these levels in the future. Applying income-based caps, similar to those available on the exchanges, to those with group insurance would have the benefit of targeting those with low incomes, without greatly increasing the cost-shifting already caused by uniform caps. However, implementing income-based caps would add a significant layer of administrative difficulty to verify the income of policy holders. Simply lowering the level of uniform caps would be an alternative, which would increase the number of those who benefit as well.

While our results suggest that few individuals will benefit from the uniform caps in any given year, it is possible that the impact will be larger over a longer time period. A similar study conducted by the Kaiser Family Foundation found that an out-of-pocket cap of $\$ 5,000$ in fee-for-service Medicare would only benefit $6.5 \%$ of beneficiaries in any given year, but approximately one third of beneficiaries would benefit in at least one year during a ten-year period. ${ }^{22}$

Our study has several limitations. First, the make-up of the insurance market could evolve over time. Given the scope of reform being implemented by the ACA, it is possible that the population represented by those with private group insurance in 2011-2012 will not reflect the same population in 2014 and beyond. Certainly, the make-up of the populations with no insurance, public insurance (i.e., Medicaid), and non-group private insurance will change considerably over this period, which is why we excluded those populations from our analysis. However, our assumption is that the group insurance market will be relatively stable. Although the impact of caps on the burden of individuals within the exchanges is of interest, enrollment in the exchanges remains in flux and the ultimate composition of these populations is not yet clear. Finally, our analyses represent an optimistic view of the impact that the caps are likely to have for several reasons. First, grandfathered health insurance plans are not required to comply with the mandated out-of-pocket caps, so the impact of the caps may be lower initially. However, in 2013, only $36 \%$ of workers were covered by grandfathered health plans, down from $56 \%$ in 2011, and this is likely to continue to decline over time. ${ }^{8}$ Second, the out-ofpocket caps only apply to services considered innetwork. As we were unable to differentiate in-network and out-of-network health spending, we were unable to account for out-of-network spending that would not be applied towards the caps.

Future research on measuring financial burden could further take into account catastrophic spending, which should be limited by out-of-pocket caps. For example, a family may be better off with $\$ 12,700$ of medical bills for the year than with $\$ 25,000$, but in both situations might be measured simply as having high financial burden using our measures. It is possible that out-ofpocket caps, even at relatively high levels, prevent catastrophic spending in ways that will lead to important reductions in measures like bankruptcy.

In conclusion, out-of-pocket spending caps included in the ACA will likely lead to small reductions in financial burden among Americans with private group health insurance. Other provisions of the ACA, such as those that mandate comprehensive coverage, may provide additional financial protection, particularly for those with lower incomes. However, if the consequences of high financial burden, such as bankruptcies, do not decrease as a result of this round of health reform, policy makers could consider stronger protections, including reduced or income-based out-of-pocket caps.

Acknowledgements: Contributors: The authors gratefully ac knowledge helpful comments on previous drafts by Craig Pollack MD, MHS, MS (Johns Hopkins University) and Brendan Saloner PhD (Johns Hopkins University).

Funders: Dr. Riggs' work on this manuscript was funded by NIH Grant T32HLOO7180 and a Hecht-Levi post-doctoral fellowship in bioethics. The funding sources had no role in the design and conduct of the study, analysis or interpretation of the data, and preparation or final approval of the manuscript prior to publication.

Prior Presentations: This work was presented in poster sessions at the Society of General Internal Medicine Annual Meeting in San Diego, California in April 2014, and at the Academy Health Annual Research Meeting in San Diego, California in June 2014.

Conflict of Interest: Dr. Riggs has no potential conflicts of interest.

Dr. Buttorff has no potential conflicts of interest.

Dr. Alexander is an ad hoc member of the US Food and Drug Administration (FDA)'s Drug Safety and Risk Management Advisory Committee, serves as a paid consultant to IMS Health, and serves on an IMS Health scientific advisory board. This arrangement has been reviewed and approved by Johns Hopkins University in accordance with its conflict of interest policies. 
Corresponding Author: Kevin R. Riggs, MD, MPH; , 2024 E. Monument Street, Room 2-604B, Baltimore, Maryland 21287, USA (e-mail: kriggs3@jhmi.edu).

\section{REFERENCES}

1. Short PF, Banthin JS. New estimates of the underinsured younger than 65 years. JAMA. 1995;274: 1302-6.

2. Alexander GC, Casalino LP, Meltzer DO. Patient-physician communication about out-of-pocket costs. JAMA. 2003;290:953-8.

3. Kullgren JT, Galbraith AA, Hinrichsen VL, et al. Health care use and decision making among lower-income families in high-deductible health plans. Arch Intern Med. 2010;170:1918-25.

4. Himmelstein DU, Thorne D, Warren E, Woolhandler S. Medical bankruptcy in the United States, 2007: results of a national study. Am J Med. 2009; 122:741-6.

5. The USA's crisis of the uninsured. Lancet 2009;373:782.

6. US Department of Health \& Human Services. Enrollment in the Health Insurance Marketplace totals over 8 million people. Available at: http://www.hhs.gov/news/press/2014pres/05/20140501a.html. Accessed November 17, 2014.

7. Patient Protection and Affordable Care Act; standards related to essential health benefits, actuarial value and accreditation. Final rule. Fed Regist 2013;78:12833-72.

8. Kaiser Family Foundation. 2013 Employer Health Benefits Survey. 2013. Available at: http://kff.org/private-insurance/report/2013employer-health-benefits/. Accessed November 17, 2014.

9. Galbraith AA, Ross-Degnan D, Soumerai SB, Rosenthal MB, Gay C, Lieu TA. Nearly half of families in high-deductible health plans whose members have chronic conditions face substantial financial burden. Health Aff (Millwood). 2011;30:322-31.

10. Cohen JW, Cohen SB, Banthin JS. The medical expenditure panel survey: a national information resource to support healthcare cost research and inform policy and practice. Med Care. 2009;47:S4450

11. Medical Expenditure Panel Survey (MEPS). Available at: http://www. meps.ahrq.gov/mepsweb/. Accessed November 17, 2014.

12. Claxton G, Levitt L, Damico A, Rae M. Data Note: How Many People Have Nongroup Health Insurance? January 2014. Kaiser Family Foundation. Available at: http://kff.org/private-insurance/ issue-brief/how-many-people-have-nongroup-health-insurance/. Accessed Accessed November 17, 2014.

13. Banthin JS, Bernard DM. Changes in financial burdens for health care: national estimates for the population younger than 65 years, 1996 to 2003. JAMA. 2006;296:2712-9.

14. Cunningham PJ. The growing financial burden of health care: national and state trends, 2001-2006. Health Aff (Millwood). 2010;29:1037-44.

15. Banthin JS, Cunningham P, Bernard DM. Financial burden of health care, 2001-2004. Health Aff (Millwood). 2008;27:188-95.

16. Bernard DS, Farr SL, Fang $\mathbf{Z}$. National estimates of out-of-pocket health care expenditure burdens among nonelderly adults with cancer: 2001 to 2008. J Clin Oncol. 2011;29:2821-6.

17. Merlis M, Gould D, Mahato B, Fund C. Rising out-of-pocket spending for medical care: a growing strain on family budgets. New York: The Commonwealth Fund; February 2006. Publication no. 887.

18. Beureau of Labor Statistics. Consumer Price Index. Available at: http://www.bls.gov/cpi/. Accessed November 17, 2014

19. Patient Protection and Affordable Care Act; HHS notice of benefit and payment parameters for 2015. Final rule. Fed Regist 2014;79:13743843.

20. Saloner B, Daniels $\mathbf{N}$. The ethics of the affordability of health insurance. J Health Polit Policy Law. 2011;36:815-27.

21. Pollitz K, Cox C, Lucia K, Keith K. Medical Debt among People with Health Insurance. January 2014. Kaiser Family Foundation. Available at: http://kff.org/private-insurance/report/medical-debtamong-people-with-health-insurance/. Accessed November 17, 2014

22. Kaiser Family Foundation. An Analysis of the Share of Medicare Beneficiaries Who Would Benefit from an Annual Out-of-Pocket Maximum under Traditional Medicare Over Multiple Years. June 2013. Available at: http://kff.org/medicare/issue-brief/analysis-ofshare-of-medicare-beneficiaries-who-would-benefit-from-out-of-pocket-maximum-over-multiple-years/. Accessed November 17, 2014

\section{APPENDIX}

Table 5. Individuals with High Financial Burden, Defined as Family Out-of-Pocket Spending Greater than $20 \%$ of Family Income

\begin{tabular}{|c|c|c|c|c|}
\hline & \multicolumn{4}{|c|}{$\begin{array}{l}\text { Family Income as \% of Federal Poverty } \\
\text { Level }\end{array}$} \\
\hline & $<200$ & $200-250$ & $250+$ & Total \\
\hline \multicolumn{5}{|l|}{ No mandated caps } \\
\hline $\begin{array}{l}\text { Health care services } \\
\text { burden (SE) }\end{array}$ & $\begin{array}{l}9.2 \% \\
(1.3)\end{array}$ & $\begin{array}{l}1.0 \% \\
(0.5)\end{array}$ & $\begin{array}{l}0.1 \% \\
(0.0)\end{array}$ & $\begin{array}{l}1.4 \% \\
(0.2)\end{array}$ \\
\hline Total burden (SE) & $\begin{array}{l}25.1 \% \\
(1.9)\end{array}$ & $\begin{array}{l}7.2 \% \\
(1.6)\end{array}$ & $\begin{array}{l}1.7 \% \\
(0.2)\end{array}$ & $\begin{array}{l}5.3 \% \\
(0.4)\end{array}$ \\
\hline \multicolumn{5}{|l|}{ Uniform caps } \\
\hline $\begin{array}{l}\text { Health care services } \\
\text { burden (SE) }\end{array}$ & $\begin{array}{l}9.1 \% \\
(1.3)\end{array}$ & $\begin{array}{l}0.9 \% \\
(0.5)\end{array}$ & $\begin{array}{l}0.1 \% \\
(0.0)\end{array}$ & $\begin{array}{l}1.4 \% \\
(0.2)\end{array}$ \\
\hline Total burden (SE) & $\begin{array}{l}24.9 \% \\
(1.9)\end{array}$ & $\begin{array}{l}7.2 \% \\
(1.6)\end{array}$ & $\begin{array}{l}1.6 \% \\
(0.7)\end{array}$ & $\begin{array}{l}5.2 \% \\
(0.4)\end{array}$ \\
\hline \multicolumn{5}{|l|}{ Reduced uniform caps } \\
\hline $\begin{array}{l}\text { Health care services } \\
\text { burden (SE) }\end{array}$ & $\begin{array}{l}8.1 \% \\
(1.1)\end{array}$ & $\begin{array}{l}0.3 \% \\
(0.3)\end{array}$ & $\begin{array}{l}0.1 \% \\
(0.0)\end{array}$ & $\begin{array}{l}1.2 \% \\
(0.2)\end{array}$ \\
\hline Total burden (SE) & $\begin{array}{l}24.5 \% \\
(1.9)\end{array}$ & $\begin{array}{l}7.2 \% \\
(1.6)\end{array}$ & $\begin{array}{l}1.5 \% \\
(0.2)\end{array}$ & $\begin{array}{l}5.1 \% \\
(0.4)\end{array}$ \\
\hline \multicolumn{5}{|l|}{ Income-based caps } \\
\hline $\begin{array}{l}\text { Health care services } \\
\text { burden (SE) }\end{array}$ & $\begin{array}{l}7.7 \% \\
(1.1)\end{array}$ & $\begin{array}{l}0.7 \% \\
(0.5)\end{array}$ & $\begin{array}{l}0.1 \% \\
(0.0)\end{array}$ & $\begin{array}{l}1.1 \% \\
(0.2)\end{array}$ \\
\hline Total burden (SE) & $\begin{array}{l}23.8 \% \\
(1.8)\end{array}$ & $\begin{array}{l}7.2 \% \\
(1.6)\end{array}$ & $\begin{array}{l}1.6 \% \\
(0.2)\end{array}$ & $\begin{array}{l}5.1 \% \\
(0.4)\end{array}$ \\
\hline
\end{tabular}

SE Standard Error

Cap scenarios are as shown in Table 1

Health care services burden includes out-of-pocket expenditures on health care services

Total burden includes out-of-pocket premiums for private insurance and expenditures on health care services

Table 6. Individuals with High Financial Burden, Defined as Family Out-of-Pocket Spending Greater than $5 \%$ of Family Income for Those Under $200 \%$ of the Federal Poverty Level, and $10 \%$ of Family Income for All Others

\begin{tabular}{|c|c|c|c|c|}
\hline & \multicolumn{4}{|c|}{$\begin{array}{l}\text { Family Income as \% of Federal Poverty } \\
\text { Level }\end{array}$} \\
\hline & $<\mathbf{2 0 0}$ & $200-250$ & $250+$ & Total \\
\hline \multicolumn{5}{|l|}{ No mandated caps } \\
\hline $\begin{array}{l}\text { Health care services } \\
\text { burden (SE) }\end{array}$ & $\begin{array}{l}26.1 \% \\
(1.9)\end{array}$ & $\begin{array}{l}3.7 \% \\
(1.0)\end{array}$ & $\begin{array}{l}1.0 \% \\
(0.2)\end{array}$ & $\begin{array}{l}4.6 \% \\
(0.4)\end{array}$ \\
\hline Total burden (SE) & $\begin{array}{l}71.5 \% \\
(1.9)\end{array}$ & $\begin{array}{l}32.5 \% \\
(3.2)\end{array}$ & $\begin{array}{l}11.8 \% \\
(0.7)\end{array}$ & $\begin{array}{l}21.6 \% \\
(0.8)\end{array}$ \\
\hline \multicolumn{5}{|l|}{ Uniform caps } \\
\hline $\begin{array}{l}\text { Health care services } \\
\text { burden (SE) }\end{array}$ & $\begin{array}{l}26.1 \% \\
(1.9)\end{array}$ & $\begin{array}{l}3.7 \% \\
(1.0)\end{array}$ & $\begin{array}{l}0.8 \% \\
(0.1)\end{array}$ & $\begin{array}{l}4.5 \% \\
(0.4)\end{array}$ \\
\hline Total burden (SE) & $\begin{array}{l}71.5 \% \\
(1.9)\end{array}$ & $\begin{array}{l}32.5 \% \\
(3.2)\end{array}$ & $\begin{array}{l}11.5 \% \\
(0.7)\end{array}$ & $\begin{array}{l}21.4 \% \\
(0.8)\end{array}$ \\
\hline \multicolumn{5}{|c|}{ Reduced uniform caps } \\
\hline $\begin{array}{l}\text { Health care services } \\
\text { burden (SE) }\end{array}$ & $\begin{array}{l}26.1 \% \\
(1.9)\end{array}$ & $\begin{array}{l}3.7 \% \\
(1.0)\end{array}$ & $\begin{array}{l}0.5 \% \\
(0.1)\end{array}$ & $\begin{array}{l}4.2 \% \\
(0.4)\end{array}$ \\
\hline Total burden (SE) & $\begin{array}{l}71.5 \% \\
(1.9)\end{array}$ & $\begin{array}{l}32.5 \% \\
(3.2)\end{array}$ & $\begin{array}{l}11.3 \% \\
(0.7)\end{array}$ & $\begin{array}{l}21.2 \% \\
(0.8)\end{array}$ \\
\hline \multicolumn{5}{|l|}{ Income-based caps } \\
\hline $\begin{array}{l}\text { Health care services } \\
\text { burden (SE) }\end{array}$ & $\begin{array}{l}25.1 \% \\
(1.8)\end{array}$ & $\begin{array}{l}3.7 \% \\
(1.0)\end{array}$ & $\begin{array}{l}0.8 \% \\
(0.1)\end{array}$ & $\begin{array}{l}4.3 \% \\
(0.4)\end{array}$ \\
\hline Total burden (SE) & $\begin{array}{l}71.3 \% \\
(1.8)\end{array}$ & $\begin{array}{l}32.5 \% \\
(3.2)\end{array}$ & $\begin{array}{l}11.5 \% \\
(0.7)\end{array}$ & $\begin{array}{l}21.4 \% \\
(0.8)\end{array}$ \\
\hline
\end{tabular}

SE Standard Error

Cap scenarios are as shown in Table 1

Health care services burden includes out-of-pocket expenditures on health care services

Total burden includes out-of-pocket premiums for private insurance and expenditures on health care services 